\title{
ANALYSIS OF HIV- TYPE 1 PROTEASE AND REVERSE TRANSCRIPTASE IN BRAZILIAN CHILDREN FAILING HIGHLY ACTIVE ANTIRETROVIRAL THERAPY (HAART)*
}

\author{
Daisy Maria MACHADO(1,2), Silvana Cláudia FERNANDES(1), Regina Célia de Menezes SUCCI(2), Wilton Santos FREIRE(1), Cláudio Sérgio PANNUTI(1),
} Aída Barbosa GOUVEIA(2), José Eduardo LEVI(1) \& Ricardo Sobie DIAZ(2)

\begin{abstract}
SUMMARY
The aim of this study was to evaluate the genotypic resistance profiles of HIV-1 in children failing highly active antiretroviral therapy (HAART). Forty-one children (median age $=67$ months) receiving HAART were submitted to genotypic testing when virological failure was detected. cDNA was extracted from PBMCs and amplified by nested PCR for the reverse transcriptase and protease regions of the pol gene. Drug resistance genotypes were determined from DNA sequencing. According to the genotypic analysis, $12 / 36(33.3 \%)$ and 6/36 (16.6\%) children showed resistance and possible resistance, respectively, to ZDV; 5/36 (14\%) and 4/36 (11.1\%), respectively, showed resistance and possible resistance to ddI; 4/36 (11.1\%) showed resistance to 3TC and D4T; and $3 / 36(8.3 \%)$ showed resistance to Abacavir. A high percentage $(54 \%)$ of children exhibited mutations conferring resistance to NNRTI class drugs. Respective rates of resistance and possible resistance to PIs were: RTV (12.2\%, 7.3\%); APV (2.4\%, 12.1\%); SQV $(0 \%, 12.1 \%)$; IDV (14.6\%, 4.9\%), NFV (22\%, 4.9\%), LPV/RTV (2.4\%, 12.1\%). Overall, 37/41 (90\%) children exhibited virus with mutations related to drug resistance, while $9 \%$ exhibited resistance to all three antiretroviral drug classes.
\end{abstract}

KEYWORDS: HIV resistance; Antiretroviral therapy; Children; Treatment failure.

Abreviations used in the paper: HAART: Highly Active Antiretroviral Therapy: ZDV: Zidovudine; 3TC: Lamivudine; D4T: Stavudine; ABC: Abacavir; NVP: Nevirapine; EFV: Efavirenz; NFV: Nelfinavir; RTV: Ritonavir; SQV: Saquinavir; IDV: Indinavir; LPV: Lopinavir/RTV; APV: Amprenavir; RT: Reverse transcriptase; Pt: Protease; NRTI: Nucleoside analogue reverse transcriptase inhibitor; NNRTI: Non-Nucleoside analogue reverse transcriptase inhibitor; PI: Protease inhibitor; PBMCs: Peripheral blood mononuclear cells.

\section{INTRODUCTION}

The main goal of antiretroviral therapy is to suppress HIV replication to the greatest extent for as long as possible. Combination drug protocols for effective viral suppression require multiple daily doses of three or more medications over an indefinite period (HAART). Despite some progress in antiretroviral therapy, the lack of adequate pediatric formulations for certain drugs, together with maintaining the treatment regimen, have created a challenging situation for pediatricians providing treatment to infants and young children.
In Brazil, antiretroviral drugs are provided free of cost by the health system to HIV-1 infected patients. The use of the three- drugs combination therapy with children was begun in 1997 at our clinical practice, and although we noted prolonged survival of the pediatric population $^{6,10}$, we encountered other serious issues such as drug resistance. The emergence of HIV resistant strains during antiretroviral therapy is one of the main reasons for treatment failure in HIV-infected children $^{3}$. Resistance of HIV-1 to antiretroviral agents results from mutations within the pol gene, which encodes for the viral reverse transcriptase (RT) and protease (Pt) regions, targets of currently used antiretroviral agents. In the present study, we analyze the genotypic resistance profiles of HIV in Brazilian children failing highly active antiretroviral therapy (HAART).

\section{METHODS}

The current study was conducted at Federal University of São Paulo, São Paulo, Brazil, between May 2000 and June 2001. The medical record review of $160 \mathrm{HIV}$-infected children attending the outpatient

(1) Instituto de Medicina Tropical de São Paulo, LIMHC-USP, São Paulo, SP, Brazil

(2) Universidade Federal de São Paulo,UNIFESP, São Paulo, SP, Brazil.

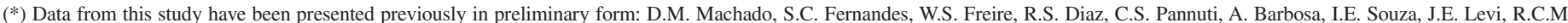

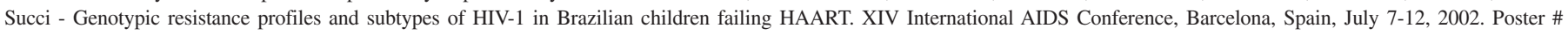
TuPeB4596.

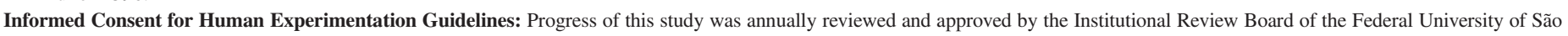

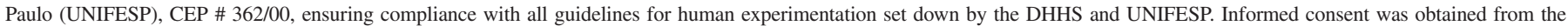
caregivers of all included children.

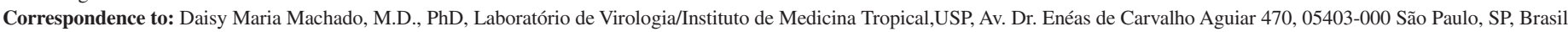
e-mail:dm.machado@uol.com.br 


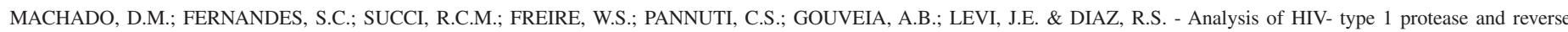
transcriptase in Brazilian children failing Highly Active Antiretroviral Therapy (HAART). Rev. Inst. Med. trop. S. Paulo, 47(1):1-5, 2005.

clinic (CEADIPe) identified 63 eligible children for this study. Eligibility requirements included: age $<18$ years; current antiretroviral treatment composed by at least 3 drugs ( 2 NRTIs plus 1 PI, or 2 NRTIs plus 1 NNRTI); displaying one of the following criteria for virologic failure $^{16}$ : a less than 10-fold decrease from baseline HIV RNA levels in those receiving two NRTIs and one PI, or a less than 5-fold decrease from baseline HIV RNA levels in those receiving two NRTIs plus one NNRTI after 12 weeks of therapy; lack of a sustained decrease in HIV RNA copy number of 1.5 to $2.0 \log 10$ from baseline; repeated detection of HIV RNA in patients who had undetectable levels prior to beginning therapy; or a persistent increase in HIV RNA levels after beginning of treatment greater than 3-fold in children aged two years or more, or greater than 5-fold in children under two years of age.

Of the 63 eligible children 41 composed the study population (Table 1). Reasons for not participating included: blood sample not available during the study period; and caregiver refusal. All children (median age $=67$ months) included had been receiving HAART ( 2 NRTIs plus 1 PI, or 2 NRTIs plus 1 NNRTI) for a median period of 12 months. The caregivers of the study participants signed an informed-consent form previously approved by the local institutional review board.

Table 1

General characteristics of the study population at the time of genotypic testing. VL, stands for the $\log _{10}$ of plasma viral load

Total of Patients (n)

Median age (months) (range)

Transmission route $(\mathrm{n})$

Vertical

Clinical category according to $\mathrm{CDC}^{*}$

A

B

C

$\mathrm{N}$

Laboratory Parameters at genotyping

$\log _{10}$ viral load (copies/ml)

CD4 (X $\left.10^{6} \mathrm{cell} / \mathrm{L}\right)$

$\mathrm{CD} 8\left(\mathrm{X} 10^{6} \mathrm{cell} / \mathrm{L}\right)$
Transfusional

\section{1}

$66(12-232)$

38

3

n \%

$12 \quad 29.3$

$12 \quad 29.3$

$15 \quad 36.6$

24.9

$\begin{array}{cc}\text { Median } & \text { Range } \\ 4.15 & 2.1-6.4 \\ 960 & 52-2748 \\ 1469 & 411-7017\end{array}$

*CDC indicates Centers for Disease Control and Prevention

Quantification of HIV-1 RNA and T-cell subsets in peripheral blood: HIV-1 RNA copy numbers (viral load) were measured using a quantitative assay (NASBA, Biomérieux, France) with a lower quantitation limit of 80 copies $/ \mathrm{ml}$. T-lymphocyte subsets in peripheral blood were quantified by flow cytometry.

HIV-1 genotyping: DNA was extracted from PBMCs and amplified by nested PCR for the reverse transcriptase (RT) and protease $(\mathrm{Pt})$ regions of the pol gene. Direct, bidirectional, dideoxynucleotide terminator cycle sequencing of the PCR product was performed using the OpenGene TMDNA Sequencing System as described elsewhere? Sequences were analyzed and manually proofread and edited.
Analysis of drug-resistance mutations: Consensus guidelines for resistance testing ${ }^{8}$ were used to define well-characterized, drugresistance mutations. These mutations and the drugs to which they are related are (primary mutations are denoted by an asterisk): Ritonavir (RTV), K20M/R, V32I, L33F, M36I, M46I/L, I54L/V, A71T/V, V77I, V82A/F/S/T*, I84V*, and L90M*; Nelfinavir (NFV) L10I, K30N*, M36I, M46I, G48V, A71T/V, V77I, I84V*, N88D, L90M*; Amprenavir (APV) V32I, M46I/L, I47V, I50*, I84V* Zidovudine (ZDV), M41L, D67N, K70R*, L210W, T215F/Y* and K219Q; Didanosine (ddI), K65R, L74V*, and M184I/V; Stavudine (d4T), V75T; 3TC, E44D*, V118I*, and M184*; Nevirapine (NVP), L100I, K103N*, V106A*, V108I*, Y181C/I*, Y188C/H/L*, and G190A*; Efavirenz L100I, K103n*, Y188C/H/L*, P236L*; and multinucleoside, Q151M, 69 insertion. Strains with genetic mixtures of mutant and wild-type sequences at amino acid sites that code for major drug resistance were considered to be drug-resistant.

\section{RESULTS}

Thirty three of 41 children exhibited complete sequences from both the RT and Pt regions. Thirty-six sequences from the RT, and 38 sequences from the Pt regions were available for analysis. According to the genotypic analysis (GuideLines ${ }^{\mathrm{TM}}$ Rules 5.0, Visible Genetics) ${ }^{7}$, 12 of $36(33.3 \%)$ children showed resistance to ZDV, while 6 showed possible resistance to this drug (16.6\%); 5/36 (14\%) and 4/36 (11.1\%) showed resistance or possible resistance, respectively, to ddI; 4/36 $(11.1 \%)$ showed resistance to 3TC and D4T; and 3/36 (8.3\%) showed resistance to Abacavir. A high percentage of children exhibited mutations conferring resistance to Nevirapine (44.4\%) and Efavirenz (38.8\%) (Fig. 1). Tables 2 and 3 show mutations related to decreased susceptibility to antiretroviral drugs and the antiretroviral therapy history, respectively. The major mutations related to PI resistance were D30N ( $\mathrm{n}=2)$, M46I $(\mathrm{n}=3)$, V82A $(\mathrm{n}=7)$ and L90M $(\mathrm{n}=2)$, corresponding to the following respective rates of resistance and possible resistance to the different drugs: RTV (12.2\%; 7.3\%); APV $(2.4 \%, 12.1 \%)$; SQV $(0 \%, 12.1 \%)$; IDV $(14.6 \%, 4.9 \%)$, NFV $(22 \%$, $4.9 \%)$, LPV/RTV $(2.4 \%, 12.1 \%)$ (Fig. 2).

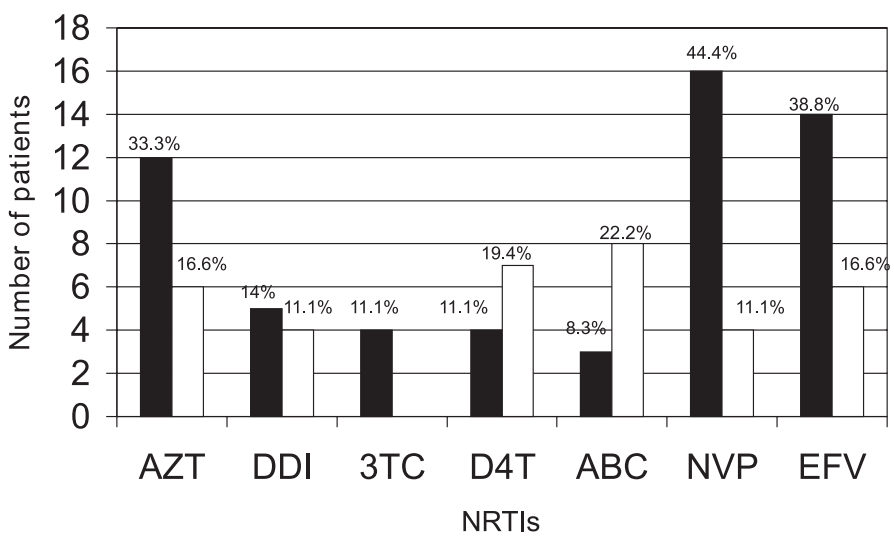

Resistance $\square$ Possible resistance

Fig. 1 - Incidence of resistance or possible resistance to NRTI and NNRTI in HIV- infected children failing HAART. $Z D V=$ Zidovudine; $3 T C=$ Lamivudine; $D 4 T=$ Stavudine $; A B C=$ Abacavir NVP $=$ Nevirapine $; E F V=$ Efavirenz 


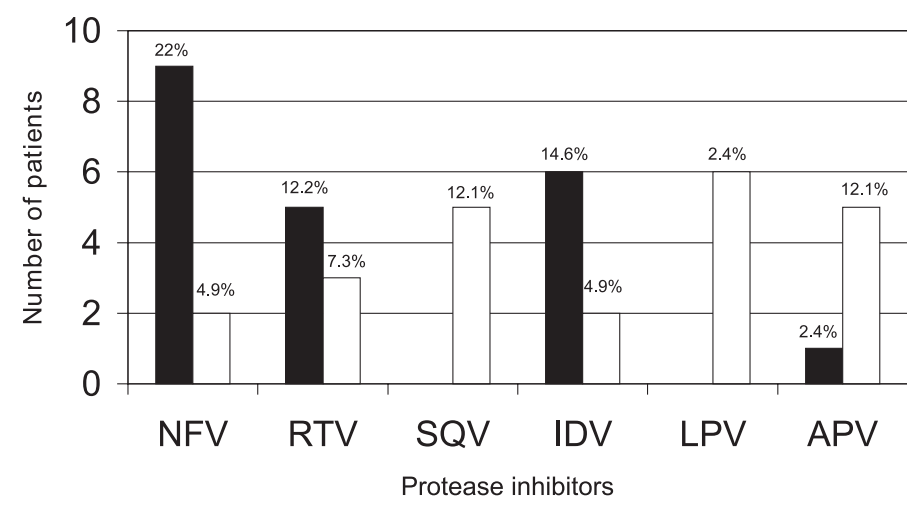

Resistance $\square$ Possible resistance
The percentages of patients with mutations related to drug resistance varied according to the drug classes employed: $57 \%$ for NRTI, 54\% for NNRTIs, and $67 \%$ for PIs.

Three of 33 (9\%) children with complete sequences from both the protease and reverse transcriptase regions of the pol gene showed resistance to all three drugs classes (MDR), while 4/33 (12\%) children showed no genotypic resistance at all.

By the time genotypic testing was performed, 19 children showed a PI-based HAART, while eight $(42 \%)$ showed resistance to this drug class. Three of eleven children (27\%) previously exposed to PIs and receiving NNRTI-based HAART were resistant to at least one PI.

\section{DISCUSSION}

Our analyses of HIV-1 from samples obtained at the time of virological failure revealed a high incidence of virus with mutations
Fig. 2 - Incidence of resistance or possible resistance to PIs in HIV infected children failing HAART. $N F V=$ Nelfinavir $R T V=$ Ritonavir $S Q V=$ Saquinavir; $I D V=$ Indinavir; $L P V=$ Lopinavir/RTV; APV= Amprenavir

Table 2

Genotypic profiles of viral isolates and antiretroviral exposure for each patient

\begin{tabular}{|c|c|c|c|c|c|}
\hline ID & $\begin{array}{l}\text { Clinical stage } \\
\text { of patient } \\
\text { (CDC) }\end{array}$ & NRTI Mutations & NNRTI Mutations & PI Mutations & Drugs used in therapy ${ }^{\mathrm{a}}$ \\
\hline 1 & B2 & none & K103N & L10V;M36I & $D 4 T / d d I / E F V, \mathrm{AZT}$ \\
\hline 2 & $\mathrm{C} 3$ & D67N;K70R;F116Y & $\mathrm{K} 103 \mathrm{~N}$ & L63P;V77I & D4T/ddI/EF VAZT;3TC;RTV \\
\hline 3 & A1 & L210W;T215Y & Y188L & M36I & $D 4 T / d d I / E F V ; \mathrm{AZT}$ \\
\hline 4 & B3 & M41L & $\mathrm{K} 103 \mathrm{~N}$ & M46I;L63P;V77I;L90M & D4T/NVP/NFV;AZT;3TC;RTV \\
\hline 5 & $\mathrm{C} 3$ & M41L;D67N;K70R;T215Y & none & L10V;K70R;M36I;I54V;L63P;V82A & $A Z T / d d I / N F V ; \mathrm{D} 4 \mathrm{~T} ; 3 \mathrm{TC} ; \mathrm{RTV}$ \\
\hline 6 & B3 & & V179I;Y181I;G190A & L10I;K20R;M36I;I54V;L63P;A71V;V82A & D4T/NVP/NFV;AZT;3TC;RTV \\
\hline 7 & B2 & $\mathrm{T} 215 \mathrm{~F}$ & A98G;L100I;K103N & L10I;K20R;M36I;I54V;L63P;V82A & D4T/ddI/EFV;AZT;3TC;RTV \\
\hline 8 & $\mathrm{C} 3$ & M41L;D67N;K70R & L100I;K103N;V108I & L24I;M36I; & D4T/ddI/EFV;AZT;3TC;RTV \\
\hline 9 & $\mathrm{C} 2$ & none & none & none & $A Z T / d d I / N F V ; \mathrm{RTV}$ \\
\hline 10 & $\mathrm{~B} 1$ & M184V;T215Y & A98E & L63P;V77I;I93L & $A Z T / d d I / N F V ; \mathrm{RTV}$ \\
\hline 11 & $\mathrm{C} 3$ & none & none & D30N;M36I;L63P;N88D & 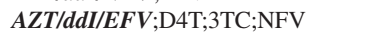 \\
\hline 12 & $\mathrm{C} 2$ & none & none & D30N;M36I;L63P;A71 V;V77I;N88D;I93L & $D 4 T / d d I / E F V ; \mathrm{AZT} ; 3 \mathrm{TC} ; \mathrm{NFV}$ \\
\hline 13 & $\mathrm{C} 3$ & none & none & K20R;M36I;F53L;L63Q & $D 4 T / d d I / E F V$ \\
\hline 14 & B3 & $\mathrm{T} 215 \mathrm{Y}$ & K103N;Y188L;G190A & M36I;L63P;V77I & $D 4 T / d d I / E F V ; \mathrm{AZT}$ \\
\hline 15 & A1 & D67N;T69N;K70R;M184V;T215F;K219Q & A98G & ND & $D 4 T / d d I / N F V ; \mathrm{AZT} ; 3 \mathrm{TC} ; \mathrm{RTV}$ \\
\hline 16 & N3 & M41L & none & L63P & $D 4 T / d d I / N V P ; \mathrm{AZT} ; 3 \mathrm{TC}$ \\
\hline 17 & $\mathrm{C} 3$ & none & none & M36I;L63S & $D 4 T / 3 T C / E F V ; \mathrm{ddI} ; \mathrm{NFV}$ \\
\hline 18 & $\mathrm{C} 3$ & none & $\mathrm{K} 103 \mathrm{~N}$ & none & $D 4 T / N F V / N V P ; A Z T ; 3 T C$ \\
\hline 19 & $\mathrm{C} 3$ & M41L;L74V & $\mathrm{K} 101 \mathrm{E}$ & M36I & $D 4 T / d d I / R T V ; \mathrm{AZT} ; 3 \mathrm{TC} ; \mathrm{NFV}$ \\
\hline 20 & A2 & M41L;D67N;T69D;K70R;T215Y & $\mathrm{K} 103 \mathrm{~N} ; \mathrm{V} 106 \mathrm{~A}$ & A71V;V82A & $D 4 T / d d I / N V P ; \mathrm{AZT} ; 3 \mathrm{TC} ; \mathrm{NFV}$ \\
\hline 21 & A2 & ND & ND & L63Q & $D 4 T / 3 T C / N V P ; \mathrm{AZT} ; \mathrm{ddI}$ \\
\hline 22 & $\mathrm{~B} 2$ & K70R;T215Y & K103N & $\mathrm{L} 10 \mathrm{~V}$ & $A Z T / d d I / E F V$ \\
\hline 23 & $\mathrm{~A} 2$ & M41L;M184I;T215Y & A98G & M36I;I47V & D4T/ddI/EFV;AZT;3TC;NFV \\
\hline 24 & B3 & ND & ND & M36I;L63P & $D 4 T / d d I / N V P ; A Z T ; 3 T C$ \\
\hline 25 & A1 & M41I;D67N;T69R;V75A;T215Y & $\mathrm{K} 103 \mathrm{~N} ; \mathrm{V} 106 \mathrm{~A}$ & L63S;A71V;V77I;V82A;I93L & $D 4 T / d d I / E F V ; \mathrm{AZT}$ \\
\hline 26 & A1 & none & none & ND & $D 4 T / d d I / N F V ; \mathrm{AZT} ; 3 \mathrm{TC} ; \mathrm{RTV}$ \\
\hline 27 & B3 & M41L;D67N;T215Y & none & M36I;L63P;V77I;L90M & $D 4 t / d d I / N F V$;AZT;3TC \\
\hline 28 & A2 & ND & ND & I93L & $D 4 T / d d I / N V P ; \mathrm{AZT} ; 3 \mathrm{TC} ; \mathrm{NFV}$ \\
\hline 29 & $\mathrm{~A} 2$ & $\mathrm{P} 236 \mathrm{~L}$ & $\mathrm{~K} 103 \mathrm{~N}$ & ND & $A Z T / d d I / R T V ; \mathrm{EFV} ; \mathrm{D} 4 \mathrm{~T} ; 3 \mathrm{TC}$ \\
\hline 30 & $\mathrm{~A} 2$ & none & none & L63P & $A Z T / d d I / R T V$ \\
\hline 31 & $\mathrm{C} 3$ & M184V & none & M36I;I54V & $D 4 T / d d I / R T V ; \mathrm{AZT} ; 3 \mathrm{TC} ; \mathrm{NFV}$ \\
\hline 32 & $\mathrm{C} 2$ & ND & ND & M36I & $D 4 T / 3 T C / N F V ; A Z T ; d d I ; N V P$ \\
\hline 33 & N2 & K70R & K103N & K20R;M36I;I54V;L63P;A71V;V82A;I93L & $D 4 T / d d I / N F V ; \mathrm{AZT} ; \mathrm{RTV}$ \\
\hline 34 & A1 & T69N;K70R;T215Y & none & M36I;L63T;I93L & $D 4 T / d d I / N F V ; \mathrm{AZT}$ \\
\hline 35 & $\mathrm{~B} 1$ & none & none & M46I;L63H & $A Z T / d d I / R T V$ \\
\hline 36 & $\mathrm{~B} 2$ & none & none & none & $D 4 T / d d I / N F V$;AZT;3TC \\
\hline 37 & $\mathrm{C} 2$ & M184V & $\mathrm{K} 103 \mathrm{~N}$ & V77I & $D 4 T / d d I / E F V ; \mathrm{AZT} ; 3 \mathrm{TC} ; \mathrm{RTV}$ \\
\hline 38 & $\mathrm{C} 3$ & none & none & L10I;V32I;M46I;I54V;A71V;V82A & $D 4 T / d d I / E F V ; A Z T ; N F V$ \\
\hline 39 & $\mathrm{C} 2$ & none & none & L63P;V77I;I93L & D4T/ddI/NFV/EFV;AZT;3TC;RTV \\
\hline 40 & A1 & V118I & A98G;Y181C & V32I & $D 4 T / d d I / N V P ; \mathrm{AZT} ; 3 \mathrm{TC}$ \\
\hline 41 & B2 & ND & ND & L63P & $D 4 T / d d I / N V P ; \mathrm{AZT} ; \mathrm{RTV}$ \\
\hline
\end{tabular}

${ }^{a}$ Drug abbreviations: AZT, zidovudine; 3TC, lamivudine; DDI, didanosine; D4T, stavudine; NVP, nevirapine; EFV, efavirenz; RTV, ritonavir; NFV, nelfinavir. The present regimen included the drugs listed in boldface, italic type. 


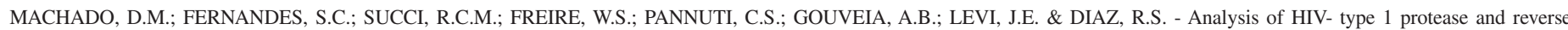
transcriptase in Brazilian children failing Highly Active Antiretroviral Therapy (HAART). Rev. Inst. Med. trop. S. Paulo, 47(1):1-5, 2005.

Table 3

Antiretroviral therapy history of 41 children failing HAART

Therapeutic history
Less than 3 prior ARV
$\geq 3$ prior ARV schemes

Patients ID

$211,3,8,9,13,14,17$,

$20,21,22,23,24,25$,

$26,30,31,33,34,35$,

40,41

$202,4,5,6,7,10,11$,

$12,15,16,18,19,27$,

$28,29,32,36,37,38$,

39

First ARV therapy

Monotherapy

8

Double therapy

$5,6,10,15,18,19$, 21,37

$1,2,3,4,7,11,12$,

$13,14,16,17,20,23$,

$24,25,27,28,29,30$,

$32,34,36,38,39,40$

HAART

9

$8,9,22,26,30,31$,

$33,35,41$

Time since first ARV scheme

$<2$ years

2-3 years

16

$1,3,9,10,13,14,17$,

$31,34,35,38,41$

$2,8,11,12,16,20$,

$22,23,24,25,28,30$,

$31,33,36,40$

$>3$ years

$4,5,6,7,15,18,19$,

$21,26,27,29,32$

37,39

Previous treatment without PI

$2,4,5,6,7,8,9,10$

$11,12,15,17,19$,

$20,23,26,28,31$,

$33,37,38,39,41$

Previous treatment with PI

23

$1,3,14,16,18,21$,

$24,25,27,29,32$,

$34,36,40$

$4 \quad 13,22,30,35$

Patients receiving the first ARV scheme

related to drug resistance (37/41; overall $90 \%$ ), with percentages varying according to specific drug classes (57\% for NRTI, $54 \%$ for NNRTIs, and $66 \%$ for PIs).

The major mutations associated with resistance to drugs not being used when the genotyping tests were performed included those related to Lamivudine (M184V; patient 10), or either Ritonavir or Indinavir (V82A; patients 5, 6, 20, 25, 33) and NNRTIs (K103N; patient 33). In some cases, these mutations may have been selected during a previous regimen and maintained by subsequent treatments ${ }^{15}$. However, this is unlikely to be the case for patients 10, 25 and 33, who exhibited principal mutations related to drugs to which they had not been previously exposed. In these three cases, a plausible explanation may be an uncommon cross-resistance phenomenon, such as M184V

selected by DDI in patient 10 , or V82A by Nelfinavir in patient 25, or less likely, primary resistance from mother-to-child transmitted resistant strains, which is probably the case for $\mathrm{K} 103 \mathrm{~N}$ in patient 33 .

Only four children were NRTI naive when HAART was begun and were experiencing their first therapeutic failures when submitted to genotypic testing (patients 13, 22, 30 and 35). Most children (90\%) had been treated with antiretroviral nucleoside RT inhibitors before beginning of HAART. Consequently, many triple drug regimens included one or two NRTIs already used by the children, and this may be one of the reasons for difficulty in adequate suppression of viral replication and the subsequent failure of ARV treatment in this population.

Several findings in this study illustrate the consequences of sequential, non-potent regimens, with subsequent, sub-optimal responses to more potent schemes. Serial monotherapy with NRTIs may have selected for thymidine-associated mutations (TAM), along with resistance to ddI, ABC and 3TC. Conceivably by the time HAART was begun, truly potent, antiretroviral regimen for these children could not be developed due to cross-resistance to the "new" NRTIs. Not surprisingly, the responses to PIs or NNRTIs were transient, with selection of resistance mutations related to these drug classes. Our patients were extensively treated with Didanosine and Stavudine, although we found a low incidence of mutations at codons 74 and 75, consistent with other published reports ${ }^{5,9}$. Although the children in this study had never received $\mathrm{ABC}$, a high percentage of resistance to this drug $(8.3 \%)$ was found, according to one of the following rules from Guidelines rules $5.0^{3}$ : NRTI 2, NRTI 3, NRTI 22. These findings again suggest cross-resistance.

Four children carried no resistance mutations in the context of a rising plasma HIV-1 RNA levels. In these cases, poor adherence to the treatment regimen should be thoroughly investigated, although cellular resistance, and/or the low, or theoretically, occasionally low, sensitivity of the test in detecting resistant strains (low negative predictive value) may be the cause ${ }^{12}$.

Our results confirm the close relationship between therapeutic failure and genotypic resistance in children, as also shown for adults ${ }^{1,14,16}$. The present study was not designed to assess whether the resistance found is the cause or the consequence of therapeutic failures. However, it is important to emphasize the possible interacting roles of adherence to the treatment regimen, regimen potency, and pharmacokinetics that may negatively influence the effectiveness of antiretroviral therapy in children.

Results like those shown here emphasize the importance of considering the appropriate moment at which to initiate ARV therapy, as well as the choice of adequate, suppressive, antiretroviral drugs. This may be especially important in children who exhibited a naturally high viral load compared to adults ${ }^{2,11}$. Thus, viral suppression with less potent regimens may not be effective considering the subsequent loss of efficacy in the succeeding regimens. The longer a child remains on a suboptimal suppressive regimen, the greater the likelihood of secondary mutations developing, and the greater the risk of subsequent, cross-resistance and drug failure ${ }^{13}$. 


\section{RESUMO}

\section{Análise da protease e transcriptase reversa do HIV-1 em crianças com falha terapêutica em uso de terapia anti-retroviral altamente eficaz (HAART)}

O objetivo deste estudo foi avaliar o perfil de resistência genotípica do HIV-1 em crianças com falha terapêutica ao tratamento antiretroviral (HAART). Quarenta e uma crianças (idade mediana $=67$ meses) em uso de HAART foram submetidas ao teste de genotipagem no momento da detecção de falha ao tratamento. Foi realizada extração de cDNA de células periféricas mononucleares e amplificação do mesmo (regiões da transcriptase reversa e protease do gene pol) através de PCR-nested. O perfil genotípico foi determinado através do seqüenciamnto de nucleotídeos. De acordo com a análise genotípica, $12 / 36(33,3 \%)$ e $6 / 36(16,6 \%)$ crianças apresentaram, respectivamente, resistência e possível resistência ao AZT; 5/36 (14\%) e 4/36 (11,1\%), respectivamente, eram resistentes e possivelmente resistentes ao ddI; $4 / 36 \% 11,1 \%)$ apresentaram resistência ao 3TC e D4T, e 3/36 (8,3\%) eram resistentes ao $\mathrm{ABC}$. Uma alta porcentagem de crianças (54\%) apresentou mutações relacionadas à resistência aos inibidores da trancriptase reversa não-análogos de nucleosídeos. As taxas de resistência e possível resistência aos inibidores da protease foram, respectivamente: RTV (12,2\%; 7,3\%); APV (2,4\%; $12,1 \%)$; SQV (0\%; $12,1 \%)$; IDV (14,6\%; 4,9\%); NFV (22\%; 4,9\%); LPV/RTV (2,4\%; $12,1 \%)$. No total, $37 / 41(90 \%)$ crianças apresentaram vírus com mutações relacionadas à resistência a alguma droga, sendo que 9\% delas tinham vírus resistentes às três classes de drogas anti-retrovirais disponíveis.

\section{ACKNOWLEDGEMENTS}

We thank the medical staff and nurses from CEADIPe and the laboratory staff from Instituto de Medicina Tropical de São Paulo for their contributions to this work.

This work was partially supported by: Fundação de Amparo à Pesquisa do Estado de São Paulo (FAPESP) - grant \# 97/00541-7.

\section{REFERENCES}

1. BACHELER, L.T.; ANTON, E.D.; KUDISH, P. et al. - Human immunodeficiency virus type 1 mutations selected in patients failing efavirenz combination therapy. Antimicrob. Agents Chemother., 44: 2475-2484, 2000.

2. DICKOVER, R.E.; DILLON, M.; GILLETTE, S.G. et al. - Rapid increases in load of human immunodeficiency virus correlate with early disease progression and loss of CD4 cells in vertically infected infants. J. infect. Dis., 170: 1279-1284, 1994.

3. ESHLEMAN, S.H.; KROGSTAD, P.; JACKSON, J.B. et al. - Analysis of human immunodeficiency virus type 1 drug resistance in children receiving nucleoside analogue reverse-transcriptase inhibitors plus nevirapine, nelfinavir, or ritonavir (Pediatric AIDS Clinical Trials Group 377). J. infect. Dis., 183: 1732-1738, 2001.
4. GALLEGO, O.; RUIZ, L.; VALLEJO, A. et al. - Rate of virological treatment failure and frequencies of drug resistance genotypes among human immunodeficiency viruspositive subjects on antiretroviral therapy in Spain. J. clin. Microbiol., 40: 38653866,2002

5. GOMEZ-CANO, M.; RUBIO, A.; PUIG, T. et al. - Prevalence of genotypic resistance to nucleoside analogues in antiretroviral-naive and antiretroviral-experienced HIVinfected patients in Spain. AIDS, 12: 1015-1020, 1998.

6. GORTMAKER, S.L.; HUGHES, M.; CERVIA, J. et al. - Effect of combination therapy including protease inhibitors on mortality among children and adolescents infected with HIV-1. New Engl. J. Med., 345: 1522-1528, 2001.

7. GUIDELINES ${ }^{\mathrm{TM}}$ Rules 5.0 Available at: http://www.trugene.com/Physicians/ GuidelineRules_5.0.pdf.

8. HIRSCH, M.S.; BRUN-VEZINET, F.; D'AQUILA, R.T. et al. - Antiretroviral drug resistance testing in adult HIV-1 infection: recommendations of an International AIDS Society-USA Panel. J. Amer. med. Ass., 283: 2417-2426, 2000.

9. HOLGUIN, A.; DIETRICH, U.; IMMELMANN, A. \& SORIANO, V. - Genotypic and phenotypic resistance to stavudine after long-term monotherapy. BMS-020 Spanish Study Group. Antivir. Ther., 3: 183-186, 1998.

10. MATIDA, L.H. - Estudo de sobrevida da AIDS em menores de 13 anos - Brasil. Bol. epidem. Ministério da Saúde, XV (2). Semanas Epidemiológicas 48A./2001-13A./ 2002.

OUTUBRO 2001 A MARÇO DE 2002. - ISSN 15171159.

11. SHEARER, W.T.; QUINN, T.C.; LA RUSSA, P. et al. - Viral load and disease progression in infants infected with human immunodeficiency virus type 1. Women and Infants Transmission Study Group. New Engl. J. Med., 336: 1337-1342, 1997.

12. SHUURMAN, R.; DEMETER, L.; REICHELDERFER, P. et al. - Worldwide evaluation of DNA sequencing approaches for identification of drug resistance mutations in the human immunodeficiency virus type 1 reverse transcriptase. J. clin Microbiol., 37: 2291-2296, 1999

13. SORIANO, V. - Sequencing antiretroviral drugs. AIDS, 15: 547-551, 2001.

14. STASZEWSKI, S.J. ; MORALES-RAMIREZ, K.T. \& TASHIMA, A. - Efavirenz plus zidovudine and lamivudine, efavirenz plus indinavir, and indinavir plus zidovudine and lamivudine in the treatment of HIV-1 infection in adults. New Engl. J. Med., 341: $1865-1873,1999$.

15. SVEDHEM, V.; LINDKVIST, A.; LIDMAN, K. \& SONNERBORG, A. - Persistence of earlier HIV-1 drug resistance mutations at new treatment failure. J. med. Virol., 68: 473-478, 2002.

16. WORKING GROUP ON ANTIRETROVIRAL THERAPY AND MEDICAL MANAGEMENT OF HIV INFECTED CHILDREN. 2004 - Guidelines for use of antiretroviral agents in pediatric HIV infection. Available at : http://www.hivatis.org.

Received: 30 August 2004

Accepted: 29 November 2004 